\title{
Financial Development and Human Capital in South Africa: A Time-Series Approach
}

\author{
Mobolaji Hakeem ${ }^{1} \&$ Oluwatoyin Oluitan ${ }^{2, *}$
}

${ }^{1}$ Department of Economics, University of Ilorin, Nigeria

${ }^{2}$ Department of Accounting \& Finance, Lagos State University, Nigeria

*Corresponding author: Oluwatoyin Oluitan, Department of Accounting \& Finance, Lagos State University, Nigeria. E-mail: roselinetoyin@yahoo.com

Received: March 11, 2012 Accepted: June 12, 2012 Published: September 8, 2012

doi:10.5296/rae.v4i3.1498 URL: http://dx.doi.org/10.5296/rae.v4i3.1498

\begin{abstract}
This is a time-series study that investigates the relationship between human capital and financial development in South Africa for the period of 1965-2005. The paper uses four measures each for both financial development and human capital. With M2 as financial indicator, the results suggest two possible directions of causality, one from human capital to financial development, and evidence of reverse causality for different measures of human capital.
\end{abstract}

With liquid liability as financial indicator, it suggests one-way directional causality from human capital to financial development. Summarily, the results suggest evidence of bi-directional causality, and that income is a possible transmission mechanism.

\section{JEL CLASSIFICATION: G20, I29 and E01}

Keywords: Financial Development, Human Capital and Economic Growth 


\section{Introduction}

Early twentieth century witnessed the upsurge of theoretical and empirical studies that document the relative importance of finance to growth. These efforts started with Schumpeter (1911), Goldsmith (1969), McKinnon and Shaw (1973) Fry (1977), and recently Estrada et al (2010), all these efforts suggest a positive and significant relationship between financial development and growth. The growing interest in Human Capital (HC) to explain growth potentials of countries has also been widely acknowledged in the literature, since the emergence of the endogenous growth theorists in the early 1990s.

The central objective of this paper is to analyse the relationship between these two major determinants of growth in South Africa. The relationship between financial development and human capital has not received considerable attention in the theoretical and empirical literature probably due to the scarcity of reliable long time data especially in the developing countries. However, there appears to be a strong positive correlation between the indicators of both financial development and the human capital in most countries regardless of their income status, most countries with high FD equally have high HC, and vice versa. (See Table 1 Correlation Matrix)

Empirical work on the issue of causality between FD and economic growth has attracted considerable attention starting with the work of Gupta (1984), Jung (1986), King and Levine (1993), Demetriades and Hussein (1996), among others. However to our knowledge, there has not been an empirical work on causality between financial development and human capital, a vacuum which this study tries to fill.

\section{Financial Development (FD) and Human Capital (HC)}

HC includes peoples' knowledge and skills, acquired through education but also the strength and vitality which depend on their health and nutrition. Well educated people have better access to information and are more likely to behave as less risk averse people (Outrivelle 1999), higher education leads to lower risk aversion and higher savings (Kelly 1980).

In Sub-Saharan Africa, the low literacy level makes people prefer to hold their wealth in the form of physical assets as against financial asset thereby inhibiting the development of the financial sector. Some others prefer to hold their wealth and keep such out of the financial system, thus inhibiting the credit creation ability of banks. Low education also leads to low development of the stock and money markets in the region. Education leads to more banking patronage, more transactions are passing through the financial system.

South Africa has high incidence of HIV-AIDS and low Life expectancy with a serious negative impact on saving and financial development. In the context of life-cycle hypothesis, the shift in demographics as a result of HIV has substantial implications for savings and financial development as the age group naturally viewed as "net savers" or potential bank customers are gradually diminishing in size. (Romm 2005). Bloom (2004) argues that health reduces man hour lost, improves the productivity of labour and leads to capital accumulation and mobilisation of savings. 
There has been some other efforts in establishing relationships between financial development and Human Capital in the literature, among them are, De Gregorio (1992), Pagano (1993), De Gregorio (1996), Outrivelle (1999) and Evans et al (2002) Papagni (2006). All of them except Evans et al (2002) and Outrivelle (1999) analysed the liquidity constraints on human capital accumulation, arguing that borrowing constraints increase aggregate savings but reduces human capital accumulation and thus have negative effects on growth. They used overlapping-generations model with endogenous growth.

Papagni (2006) goes further to argue that if liquidity constraints of the youths are reduced by their parents assurance of the loan repayment with their income, then human capital accumulation can be enhanced and thus growth. A stable trap of low development is characterised by high fertility rates and low investment in Human capital. Parents care about children's education especially where it is considered as an investment, with a positive net return to both the children and the parents, thus the parents choose a collateral which depends positively on family income and negatively on family size.

None of these efforts empirically investigated the causal relationship between Human capital and financial developments, especially in South Africa. To our knowledge this is the first time this type of study is being carried out.

De Gregorio (1992) argues that if households borrow to finance accumulation of human capital, the effect of this liquidity constraint on growth is ambiguous, human capital accumulation raises saving rate in the long-run but lowers the productivity of investment in the short-run. Low level of $\mathrm{HC}$ reduces overall savings in the economy and increases domestic credit to the private sector to cater for education matters.

Evans et al (2002) suggest a positive relationship between money and human capital and provides evidence for complementarity between Financial Development and Human capital and conclude that a developed financial system is an essential complement to a human resources or manpower development in the growth process. However, Ukenna et al (2010) opines that training and skill are better predictors of $\mathrm{HC}$ that readily impact growth. To achieve significant result, industries will need to train and retrain their staff to acquire needed skills that are essential for high performance that ultimately stimulate growth

Due to the intergenerational effects and the irreversibility nature of the HC components, as well as the importance of FD in enhancing growth in SSA this study attempts to analyse which causes what and which comes first, $\mathrm{HC}$ accumulation or FD, this shall provide a strong policy implication for the government and people in the region, especially in this era of reforms, where the emphasis has been on proper sequencing of reform efforts (Mckinnon 1991)

\section{Explaining financial underdevelopment in developing countries: A survey}

Demetriades et al (2006) observe that it is well documented in the literature that a well functioning financial system can help promote economic growth in the middle income countries (Rioja and Valev 2004, Demetriades and Andrianova 2004). 
Patrick (1966) differentiates between a supply leading and a demand following pattern of financial development, Supply leading implies that the financial sector precedes and induces real growth, while the real sector develops and financial sector development follows in the demand following pattern. Empirical evidence in the literature suggests that developing countries have a supply -leading causality pattern of development rather than a demand-following pattern (Fritz 1984).

Several empirical works have identified other non- financial factors that have impacted on financial development, these factors include technology (Merton 1992), fiscal policies (Bencivenga and Smith 1991), legal system (La Porta et al 1996), institutional qualities (Demetriades et al 2005), political economy (Rajan and Zingales 2003) however none has robustly examined the impact of human capital on financial development especially in South Africa.

The causality test in this paper is preceded by cointegration test as it is known that the existence of cointegration has implications for causality testing (Granger, 1988, Sims et al, 1990) and also provides evidence for the existence of a stable long-run linear relationship between the two or more variables of concern. The paper is divided into five sections: the econometric issues on causality are discussed in section 2, section 3 discusses the data, its sources and measurement, section 4 gives the results and section 5 concludes the paper.

\section{Econometric Issues: Unit Root, Cointegration and Causality}

Causality (ability of one variable to predict and therefore cause the other) was first developed by Granger (1963)

In econometrics, two causality tests are popular; these are the ECM-based Granger causality test and the Johansen test. However, there appears no general consensus as to the potency of either of the two causality tests. While Sims et al (1990) argue that when variables are cointegrated, the conventional Wald test statistic converges to a chi-square (k) distribution under the null hypothesis of non-causality, thus not necessary to difference $I(1)$ variables, before carrying out the granger causality test and so support the use of the Granger causality testing procedure. Toda and Phillips (1993) suggest that Johansen-type ECMs offer a better basis for causality testing. Thus, due to differences in econometric approaches to causality testing, the paper conducts a variety of causality tests between financial development and Human capital in South Africa using both the levels VAR and ECM representation. The testing procedure commences with the unit root tests aim at establishing the order of integration of each variable, this is followed by a cointegration test to establish the long run relationship and stability of the model.

The unit root tests were conducted using the Dickey -Fuller (1981), and Phillip-Perron Procedure and DF-GLS tests. However, given that ADF tests tend to be sensitive to the order of augmentation, the general to specific procedure suggested by Campbell and Perron (1991) was used. 
For the cointegration tests, the two popular procedures of Engle and Granger (EG) (1987), and Johansen (1988), were utilised however the Dynamic OLS (1990) was also used to confirm the results from the two tests.

The dynamic ordinary least squares (DOLS) estimator which has been used in many empirical works (Saikkonen (1991), Stock and Watson (1993, Demetriades and Luintel 1997) has been found to be asymptotically equivalent to Johansen's maximum-likelihood estimator in the case where variables are $I(1)$ and there is a single cointegrating vector. Stock and Watson (1993) also found it to perform well in finite samples relative to other asymptotically efficient estimators. The small sample properties of the DOLS estimator are particularly useful in our study, due to the limited data availability. Engel-Granger estimator has been found to exhibit substantial bias (Banerjee et al 1986), Stock and Watson (1993). Other advantage of the DOLS over the SOLS (static OLS or Engel-Granger OLS) as enumerated by Dematriades and Luintel (1997), is that while SOLS suffers from a non-standard asymptotic distribution, the DOLS is asymptotically normally distributed. Thus statistical inference on the parameters of the cointegrating vector is possible, even in small samples (Park and Phillips 1988), (Demetriades and Luintel 1997). The DOLS equation incorporates lags and leads of first differences of the $I(1)$ variables.

Given the fact that Engel-Granger, Johansen tests and DOLS were conducted and reported in this paper, where there is a conflict between the two tests, the DOLS estimation is chosen if it confirms either the Engel-Granger or Johansen tests, this serves as a more reliability test for the model. Though it is now known that the Engel-Granger technique suffers from poor finite sample properties which may result in large bias in the OLS estimates of cointegrating vectors (Banerjee et al 1986). Also (Hall 1989) argues that Johansen procedure is a powerful way of analysing data, because it allows a complex interaction and structure which allows us to understand systems in a much deeper way.

\section{Exogeneity and Cointegration}

Where cointegration is found, the residual of the cointegration vectors obtained from the ECM is used to test the causality and to establish weak or strong exogenity. We perform three types of causality tests, depending on the source of causation. The first type relates to the joint significance of lagged dynamic terms (i.e $\Delta x_{1 t-1}$ in the $\Delta x_{2}$ equation and $\Delta x_{2 t-1}$ in

the $\Delta x_{1}$ equation). The second is a test of statistical significance of the lagged cointegrating vector in each of the two equations (i.e $\alpha_{2}=0$ in the $x_{2}$ equation and $\alpha_{1}=0$ in the $x_{1}$ equation). This is a test of weak exogeneity and an indication for the error correcting behaviour of the variable. The third is a test of the joint significance of both lagged dynamic and error correction terms, which is also a test for strong exogeneity (Charemza and Deadman 1992). 
Given the wide range of causality tests performed, we expect some results from these different techniques to be at variance, or simply contradictory. In such cases, where the ECM based results produce results which are different from those obtained from the levels VAR approach, the study gives preference to the ECM over the VAR approach.

\section{Measurement and Data sources}

In the literature, human capital has been broadly defined to include education, health, training, migration and other investment in human beings. Empirical works on human capital has often decomposed human capital accumulation into both education human capital and health human capital. The two broad categories have been found to have different impacts and transmission mechanisms on growth and development. While Hojo (2003) argues that education accelerates growth indirectly through productivity improvements, Bloom (2002) and others have found a stronger and more robust relationship between health human capital and growth especially in developing countries. Others have favoured or argued for the complementarities between the two, thus in this study, we use three indicators of education human capital and one indicator of health human capital. This study uses the primary school, secondary school, tertiary institutions enrolment rates, as indicators of education human capital and life expectancy at birth as an indicator of health human capital.

Financial development indicators used in this study are the indicators commonly used in the empirical studies (See Demetriades and Androvana 2004, King and Levine 2003 etc). These indicators include the ratios of M2/GDP, M3/GDP, DC/GDP and DCp/GDP. The $\mathrm{M} 2 / \mathrm{GDP}$ is a ratio that measures the degree of monetization in an economy, as well as the overall size of the financial sector (king and Levine 1993). It is also an indicator of the financial deepening in an economy (Feldman and Gang 1990). It has been widely used in many empirical studies (Gelb 1989, World bank 1989; King and Levine 1993) though using this ratio as an indicator of financial development has been subtly criticised by Demetriades and Hussein (1996) when they observe that this ratio has to do more with the extent to which transactions are monetised than with the degree of financial intermediation, especially in the developing countries where substantial component of the broad money is held outside the banking system. However, this supports the McKinnon's outside money model in which the accumulation of real money balances is necessary for self-financed investment. They finally conclude it may be useful in developing countries and at an early stage of economic development when barter transactions are being replaced by market transactions.

De Gregorio and Guidotti (1992) argue that monetary aggregates are unstable measures of the financial system and that domestic credit should take precedence in measuring the impact of finance on growth. Hence, this study also used the ratio of domestic credit to GDP, and specifically the ratio of domestic credit to the private sector to the GDP, this is in consonance with the inside money model of McKinnon and Shaw. It also provides more direct information on the extent of financial intermediation in a country. This ratio is responsible for the quantity and quality of investment and, in turn the economic growth. This ratio could also provide an insight into human capital accumulation, especially in period of insufficient government support for education and health. This is also likely to have a causal 
relationship with the real GDP Per Capita. Other indicator of financial development used in this study is the liquid liability ratio which has been used in many empirical works

This paper is a time series study for South Africa and the study period is from 1965 to 2005. Due to the rudimentary stage of the capital market, and the non-availability of complete data set for the relevant period of the study, the capital market development indicators could not be used. In consonance with the earlier works (Gelb 1989, King and Levine 1993), the study used real GDP per Capita as an indicator for economic development. Heston (1994) observes that the real GDP per capita is a reliable indicator of economic well being, is prone to fewer errors than the GDP figures and also aids intertemporal comparison.

The majority of the data are sourced from the World Bank Tables (WBT); World Development Indicators (Various issues), data on education was obtained from Fedderke (South Africa, 2001), Barro and Lee (2000) and World Development Report (2006). All the variables in the data set are first transformed into the natural logarithm for obvious statistical reason of standardisation and equalisation of the variables. The study spans through 1965-2005, thus it consists of 41 annual observations.

\section{Discussion on the results}

The preliminary stage starts by examining the stationarity properties of the variables. We test for the order of integration using the Augmented Dickey-Fuller ADF (1979) test for unit root. Though ADF is most commonly used in empirical work, but it has been observed that the ADF corrects for higher order serial correlation by adding lagged difference terms on the right hand side, and in small samples the reduced degrees of freedom can affect the power of the test. Hence, we apply the Phillip-Perron PP (1988) to confirm the results. The PP test is better in this regards, thus both tests are often used in empirical works, and if they confirm each other then greater confidence can be placed on the results (Enders, 1985).

However, one potential problem with both ADF and PP tests is that they take a unit root as the null hypothesis. Blough (1992) observes that unit root tests have a high probability of falsely rejecting the null hypothesis of non-stationarity when the data generation process is close to stationary process. This is because in finite samples, some unit root processes display behaviour closer to stationary white noise than to a non stationary random walk, while some trend stationary processes behave more like random walks (Harris, 1995). Unit root tests with high power against any stationary alternative will have a high probability of a false rejection of the unit root when applied to near stationary processes. In lieu of this, we also utilise the DF-GLS test to confirm the validity of the ADF and PP test results.

The results from the unit root tests are presented in Table 3. If a variable is confirmed to be I(1) by the three tests, then we use it in the cointegration tests, if however there is ambiguity concerning the stationarity, we use the DF-GLS result. 


\section{Macrothink}

Research in Applied Economics

ISSN 1948-5433

2012, Vol. 4, No. 3

Table 3: Augmented Dickey-Fuller (ADF) and Philips-Perron Unit Root Tests for variables for the period 1960-2005 for South Africa

\begin{tabular}{llllllllll}
\hline & \multicolumn{3}{l}{ ADF } & \multicolumn{3}{c}{ Phillips-Perron } & \multicolumn{2}{l}{ Dickey- Fuller -GLS } \\
Variables & At & In First & At Level & In First & At Level & In First & Order of \\
& Level & Difference & & Difference & & Difference & Integration \\
\hline LM3/Y & -0.99 & $-4.58^{*}$ & -1.2 & $-4.59^{*}$ & -0.92 & $-4.62^{*}$ & I (1) \\
LM2/Y & -1.89 & $-4.31^{*}$ & -0.77 & $-4.31^{*}$ & $-2.06^{* *}$ & $-4.31^{*}$ & I (1) \\
LDC/Y & -1.12 & $-8.14^{*}$ & -0.68 & $-7.98^{*}$ & -0.08 & $-7.10^{*}$ & I (1) \\
LDCp/Y & -0.81 & $-5.72^{*}$ & -0.81 & $-5.72^{*}$ & 1.01 & $-2.74^{*}$ & I (1) \\
LPry Enr & -2.53 & -2.02 & -2.12 & -1.99 & -0.59 & $-2.03^{* *}$ & I (1) \\
LSec Enr & -2.46 & $-2.64^{* * *}$ & -1.47 & $-2.79^{* *}$ & -0.49 & $-2.71^{*}$ & I (1) \\
LTer Enr & -1.27 & $-4.63^{*}$ & -1.6 & $-4.63^{*}$ & -1.31 & $-4.56^{*}$ & I (1) \\
LLE & $-3.06^{* *}$ & $4.04^{*}$ & -0.26 & -1.75 & $-2.07^{* *}$ & 0.81 & I (0) \\
LY & -2.40 & $-2.79^{* * *}$ & -2.07 & $--3.41^{* *}$ & -0.81 & $--3.22^{*}$ & $1(1)$ \\
LI/Y & -1.29 & -6.36 & -1.13 & $-8.66^{*}$ & -1.19 & $-5.86^{*}$ & I (1) \\
& & & & & & & \\
\hline
\end{tabular}

Note: $* * * * * *$ indicate that we reject the null hypothesis of unit root at $1 \%, 5 \%$ and $10 \%$ respectively. All variables are stationary at first difference and most significant at $1 \%$ level in first difference. See list of variables in the appendix for details.

Table 4: Engel -Granger Cointegration Tests of the Bivariate Models

\begin{tabular}{|c|c|c|c|}
\hline \multicolumn{4}{|l|}{ Null hypothesis: $r=0$} \\
\hline $\begin{array}{l}\text { Variables in cointegration } \\
\text { vector }\end{array}$ & $\begin{array}{l}\text { ADF } \\
\text { t-statistics }\end{array}$ & CV & Conclusion \\
\hline LDC, LY & $-3.27^{* \star *}$ & 3.12 & Reject $\mathrm{H}_{\mathrm{o}}$ \\
\hline LDCp, LY & -2.04 & 3.41 & Do not Reject $\mathrm{H}_{\circ}$ \\
\hline \multirow[t]{2}{*}{$\mathrm{LM}_{2}, \quad \mathrm{LY}$} & $-3.47^{* *}$ & & Reject $\mathrm{H}_{\circ}$ \\
\hline & & 3.41 & \\
\hline \multirow[t]{2}{*}{$\mathrm{LM}_{3}, \mathrm{LY}$} & $-3 . .63^{* *}$ & & Reject $\mathrm{H}_{\mathrm{o}}$ \\
\hline & & 3.41 & \\
\hline
\end{tabular}

Note: The cointegration test is on the residuals of the Equations, using ADF test. Please note that *;*and $* * *$ indicate significance at $1 \%, 5 \%$ and $10 \%$ respectively, indicating rejection of the null hypothesis of no cointegration among the variables. The critical value is based on McKinnon 1991. $\mathrm{k}=1$, degree of augmentation. See list of variables in the appendix for details. 


\section{Macrothink}

Table 4b: Johansen Cointegration Tests of the Bivariate Models

\begin{tabular}{|c|c|c|c|c|}
\hline \multicolumn{5}{|c|}{ Null hypothesis: $r=0,1$ See appendix for details on the list of variables. } \\
\hline \multirow[b]{2}{*}{$\begin{array}{l}\text { Variables in } \\
\text { cointegration vector }\end{array}$} & \multicolumn{2}{|c|}{ Trace Statistic } & \multicolumn{2}{|c|}{ Maximal Eigenvalue Statistic } \\
\hline & $r=0$ & $r=1$ & $r=0$ & $r=1$ \\
\hline LDC, LY & $15.8^{* *}$ & $6.80^{* *}$ & 9.01 & $6.80^{\star *}$ \\
\hline LDCp, LY & 8.22 & 1.79 & 6.42 & 1.79 \\
\hline LM2, LY & $15.6^{* *}$ & $3.88^{* *}$ & $15.6^{\star *}$ & $3.88^{* *}$ \\
\hline LM3, LY & $20.6^{*}$ & $4.71^{\star *}$ & $17.6^{* *}$ & $4.71^{* *}$ \\
\hline
\end{tabular}

Table5a: Engle-Granger cointegration tests Trivariate Models

\begin{tabular}{|c|c|c|}
\hline Variables in Cointegrating Vector & Engel-Granger ADF & DOLS \\
\hline $\mathrm{LM}_{3}, \mathrm{LY}$, , LTer & -2.57 & 1.87 \\
\hline $\mathrm{LM}_{2}, \quad \mathrm{LY}$, , LTer & -2.52 & 2.35 \\
\hline LDC LY , ,LTer & $-3.83^{\star *}$ & $-3.85^{5 *}$ \\
\hline LDCp, LY,LTer & $-3.96^{* *}$ & 0.89 \\
\hline LM3, LY LLE & $-3.60^{* \star *}$ & $-4.56^{*}$ \\
\hline LM2 LY LLE & -2.35 & $-3.90^{* *}$ \\
\hline LDc, LY LLE & $-4.39^{*}$ & $-3.88^{* *}$ \\
\hline LDCp, LY LLE & $-3.90^{\star *}$ & 1.69 \\
\hline $\mathrm{LM}_{3} \mathrm{LY}, \mathrm{LSEC}$ & 1.93 & $-4.51^{*}$ \\
\hline $\mathrm{LM}_{2}, \quad \mathrm{LY}, \mathrm{LSEC}$ & -1.87 & $-3.89^{* *}$ \\
\hline LDC, LY, LSEC & $-3.18^{\star \star \star}$ & $-3.23^{\star \star \star}$ \\
\hline LDCp, LY , LSEC & $-3.95^{\star *}$ & -2.25 \\
\hline LDC, LY, LPRY & -1.86 & $-4.01^{* *}$ \\
\hline $\mathrm{LM}_{3}, \quad \mathrm{LY}, \mathrm{LPRY}$ & 1.82 & $-4.20^{\star *}$ \\
\hline $\mathrm{LM}_{2}, \quad \mathrm{LY}, \mathrm{LPRY}$ & -1.11 & -2.56 \\
\hline LDCp, LY , LPRY & -1.01 & -2.02 \\
\hline
\end{tabular}

Note: The cointegration test is on the residuals of the Equations, using ADF test. Please note that $* * *$ and *** indicate significance at 1 percent, 5 percent and 10 percent respectively, indicating rejection of the Null hypothesis of no cointegration among the variables. The critical value is based on McKinnon 1991. $\mathrm{k}=1$, degree of augmentation. See list of variables in the appendix for details. 
Table 5b: Johansen Cointegration Tests of the Trivariate Models

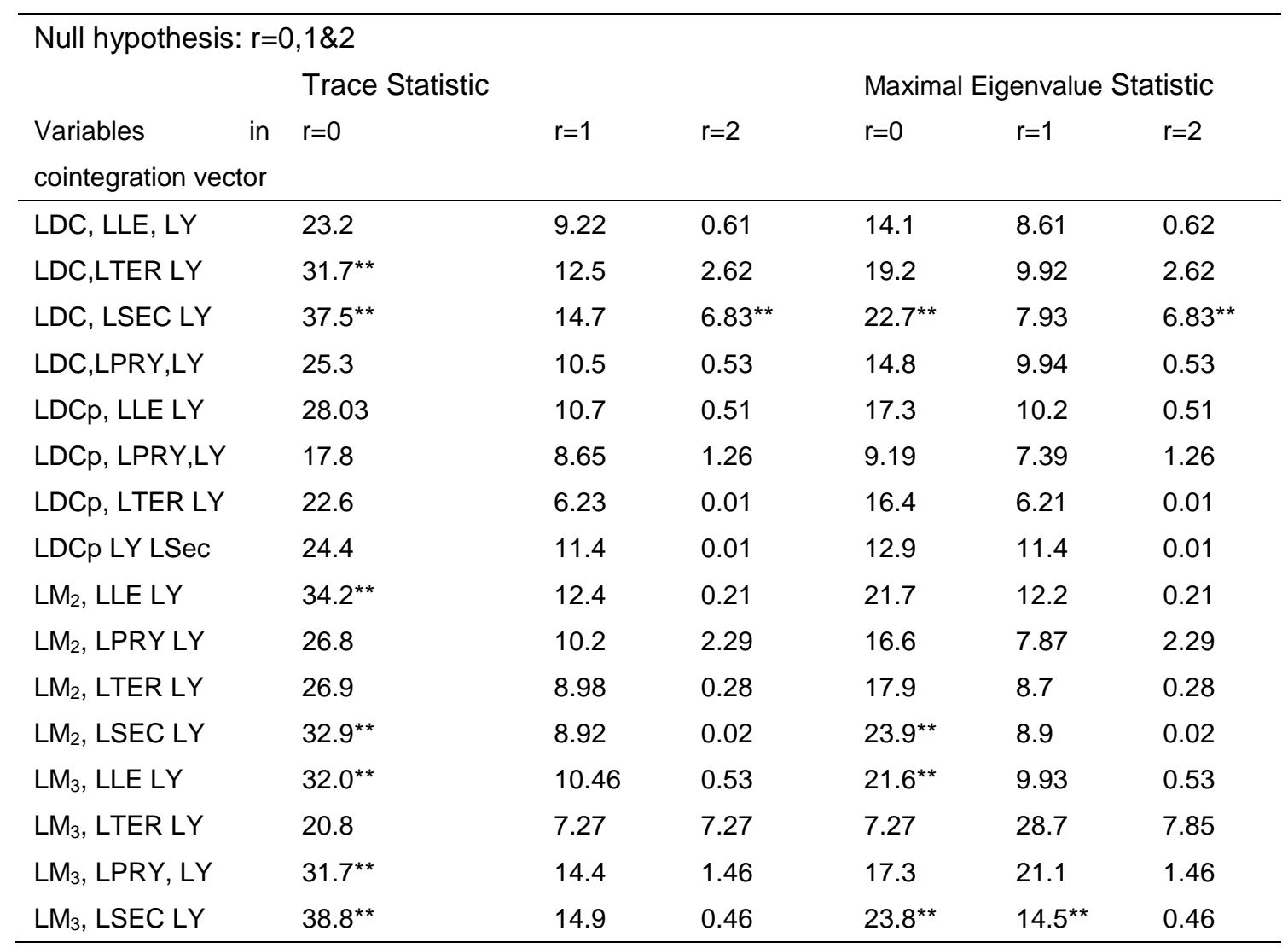

See list of variables in the appendix for details.

Table 6: Test of the significance of the variables, and their LR impacts on the cointegration models

\begin{tabular}{|c|c|c|c|c|c|c|}
\hline \multirow[b]{2}{*}{ Variables } & \multicolumn{3}{|c|}{ Null Hypothesis: $\beta_{i}=0$} & \multicolumn{3}{|c|}{ Null Hypothesis: $\alpha_{i}=0$} \\
\hline & $H_{o}: \beta_{f d}=0$ & $H_{o}: \beta_{y}=0$ & $H_{o}: \beta_{h c}=0$ & $H_{o}: \alpha_{f d}=0$ & $H_{o}: \alpha_{y}=0$ & $H_{o}: \alpha_{h c}=0$ \\
\hline $\begin{array}{l}\text { LDC,LTER } \\
\text { LY }\end{array}$ & $18.0^{*}$ & $7.19 * *$ & 1.99 & 0.94 & $13.73^{*}$ & 2.03 \\
\hline $\begin{array}{l}\text { LDC, } \\
\text { LSEC LY }\end{array}$ & $23.6^{*}$ & $17.0 *$ & $3.08 * * *$ & 0.21 & $24.02^{*}$ & 0.02 \\
\hline $\begin{array}{l}\mathrm{LM}_{3}, \quad \text { LLE } \\
\mathrm{LY}\end{array}$ & $7.13 *$ & $7.31 *$ & 0.92 & $9.15^{*}$ & $3.23 * *$ & 0.77 \\
\hline $\begin{array}{l}\mathrm{LM}_{3}, \\
\mathrm{LPRY}, \mathrm{LY}\end{array}$ & $3.17 * * *$ & 0.03 & $2.99 * * *$ & 0.01 & $2.74 * * *$ & $3.93 * *$ \\
\hline $\begin{array}{l}\text { LM3, } \\
\text { LSEC, LY }\end{array}$ & $11.7 *$ & $5.02 *$ & $5.55^{*}$ & $13.29 *$ & 1.91 & 2.21 \\
\hline $\begin{array}{l}\text { LM2 } \\
\text { LTER,L Y }\end{array}$ & $7.48 *$ & $15.7 *$ & 0.12 & $13.9 *$ & $9.28 *$ & $2.65^{* * *}$ \\
\hline $\begin{array}{l}\text { LM2, } \\
\text { LSEC,LY }\end{array}$ & $6.12 *$ & $13.6^{*}$ & 0.04 & $9.08 *$ & $7.08^{*}$ & 0.65 \\
\hline
\end{tabular}

See list of variables in the appendix for details. 


\section{Mll Macrothink}

Table7: Causality Tests Results

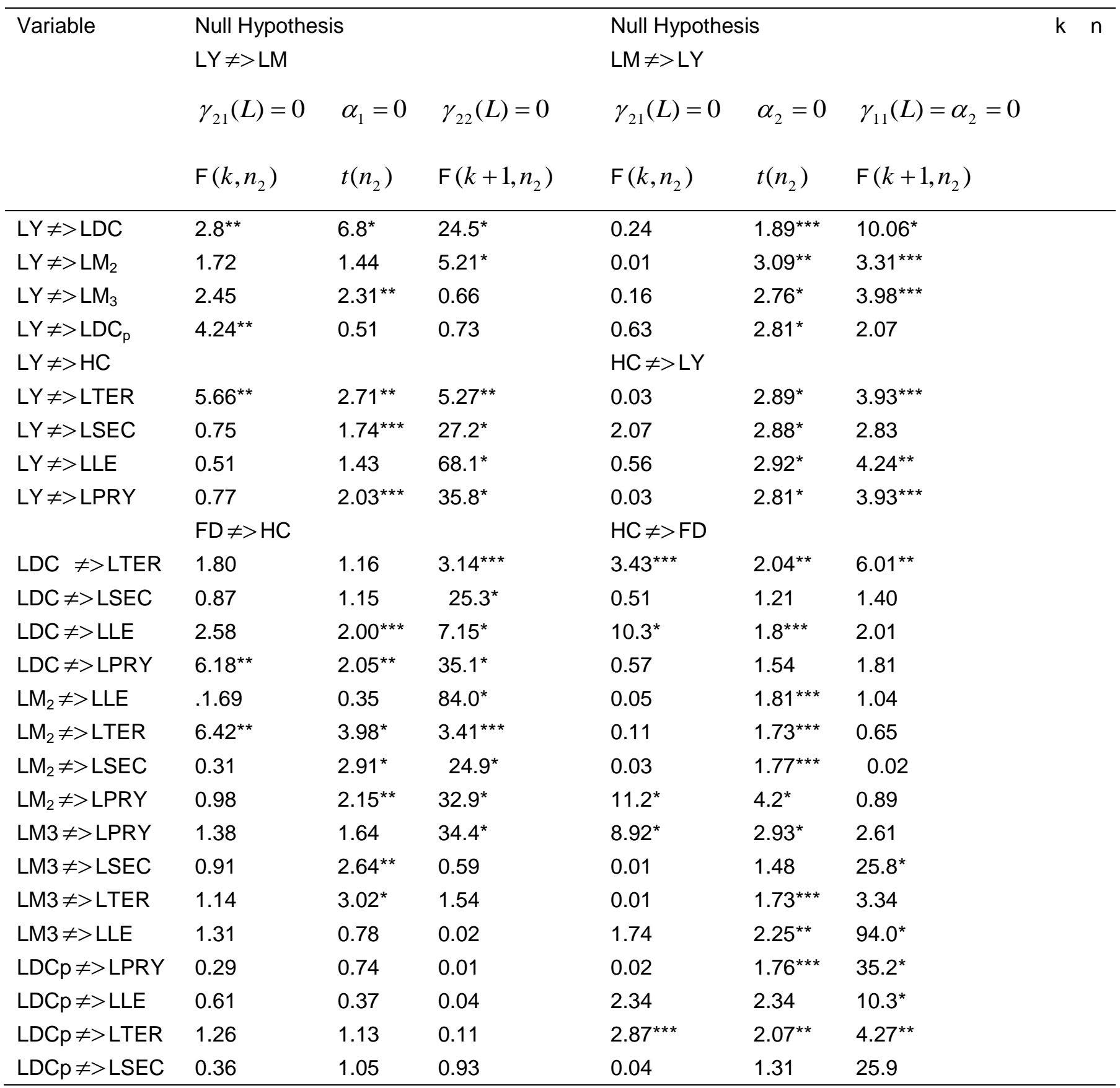

The results of the unit root tests are reported in table3. With the exception of the primary enrolment (Pry Enr) variable, all the three tests suggest that all the variables are $I(1)$. The hypothesis of a unit root in the logarithm of primary school enrolment cannot be rejected by ADF and PP tests. However, the DF_GLS showed that the variable is an I(1) series. Given the results of the unit root, it is possible to use cointegration methodology in order to test for the existence of a stable relationship between economic growth, financial development and human capital. 
Table 4 and 4a report the cointegration tests based on the Engel and Granger(1987) Johansen (1988) tests for the bivariate models. The study starts with a bivariate model of both the economic growth and financial development. This exercise is done to verify the theoretical postulation about the relationship between financial development and economic growth using Isouth Africa as a case study.

The test statistics reported are the augmented Dickey-Fuller $(\mathrm{ADF}(\mathrm{k}))$ tests relating to the hypothesis of a unit root in the cointegrating regression residuals. The Johansen tests are based on the maximum likelihood estimates of a vector autoregression. The null hypothesis is that there is no cointegration vector and the alternative is that there is one cointegrating vector. We report both the trace test, which is akin to a vector DF test, and the maximal eigenvalue test associated with each lag length in order to examine whether the outcome of the cointegration test is sensitive to the order of the VAR.

The Engel -Granger cointegration test results for the bivariate model reported in table 4 suggest that three of the financial indicators cointegrated with the real GDP, while the null hypothesis of no cointegration could not be rejected in the relationship between $\mathrm{M}_{2}$ and the real GDP in South Africa for the period under review. All tests were significant at $10 \%$. The Johansen test results in table $4 \mathrm{~b}$ are more encouraging, they detect more cointegration relationships even at $1 \%$ significance level. Though the Johansen test results are more encouraging as it detects more cointegration relationship than the Engel-Granger, however these results may be sensitive to the lag length of the VAR as suggested by Banerjee et al (1993).

The study then gradually introduced the human capital index into the bi-variate model and test the significance of the new variable in the model, by testing the significance of the $\beta$ coefficient of the human capital in the model, the results of the LR test are reported in table 5. For the Tri-variate model, Engel-Granger method could only detect cointegration relationship in five model specifications as against seven that were detected by Johansen Method, at five percent significance level. We then restrict the $\beta$ coefficient of each of the three variables to zero and conduct the likelihood ratio test for the binding restriction (LR test) for the model specifications where cointegration relationship is detected. The most important variable here is the new variable, the human capital variable that has just been introduced into the bi-variate models.

The null hypothesis is that the variable of concern is not significant and the alternative hypothesis is that the variable is significant. The rejection of the null hypothesis indicates that the variable is important in the cointegration vector, and can explain a longrun stable relationship in the model. Thus a non-rejection of human capital variable indicates that human capital is not significant in explaining the long run relationship among the variables in the model. The results are presented in table 6, in three of the models, the human capital variables were actually significant, since the result of the likelihood ratio (LR) or Chi-Square test rejects the null hypothesis that the variable is insignificant, while in four of 
the models, the Human capital indicator was not significant, this could be due to the quality of data or a confirmation of the general observation or findings in the literature that human capital variables are often found to be empirically insignificant (see Hojo:2003). The Human capital indicators that are significant include the life expectancy at birth and secondary school enrolment.

The life expectancy has a strong correlation with savings and borrowing cultures of people, an individual with a relatively low death threatening illness or strong health is likely to be more responsive to financial sector development than a weaker or somebody with a poor health, who is likely to liquidate all his savings for his medical bills. Also with about 90\% enrolment ratio in secondary school, this creates a workforce with high literacy and it has been argued that more educated individuals have high saving culture, high patronage of the financial sector and are more willing to take financial risks. Again we observe that Life expectancy and secondary school enrolment appear to be the relevant indicators for Human capital in South Africa, and they are relevant to financial development as well as longrun growth in the country. Financial development indicators and real GDP Per Capita are significant in all the different model specifications, showing that these two variables were relevant to the models specified.

A similar exercise was done for the $\alpha$ coefficients to test the longrun effects of each of the variables of interest. The null hypothesis is that the variable does not have any long run effect on the model, while the alternative hypothesis is that the variable has a long run effect on the model. The result of the likelihood ratio (LR) and Chi-Square tests are also reported in table 6.

In all, the study suggests that both tertiary education and life expectancy are the only two indicators of the human capital that have a log run effect on both the financial sector and the economy. Tertiary education has a longrun effect on the financial development and the long run growth path of the country. This is in consonance with the findings of Aghion (1993) where he stressed the growth impact of tertiary education. Also the life expectancy guarantees more useful life span of human resources for both the financial development and the overall economic growth. It stresses the continuous use of the productive efforts of the human resources for both the financial sector in particular and the overall economy in all.

It is only the model specification where we run Domestic Credit to the private sector, with Life Expectancy and Real GDP Per Capita, that the human capital indicator, the life expectancy was not significant, thus we could not reject the null hypothesis. This suggests that the private credit does not really have impact on the human capital accumulation in South Africa for the period under consideration or it could suggest that substantial credit is transferred to the public or government as against the private sector, and that the little available are used for keeping the subsistence level of the household.

However, in all, the real GDP Per Capita growth rate appears to be the dominant engine for long run growth in the economy, as we reject the null hypothesis that the variable does not have a longrun effect on both human capital accumulation and financial development in six 
out of seven of the cointegrated model specification. We do not reject the null hypothesis of the long run effect of real GDP only where the M2 and life expectancy were used. However, we reject the null hypothesis of the long run effect of the financial development in four models, and we do not reject the null hypothesis in three models. Thus, this suggests that the South Africa economy is Supply -leading economy in line with Patrick (1967) hypothesis of Supply leading, where he argued that most developing countries pursue supply-leading and not demand-following economies.

Given the results from the cointegration tests, we then conducted the Granger causality tests for pairs of variables for which the three techniques show evidence of cointegration at least at 10\% level significance level. These include LM3, LY and LLE, LDC, LY SEC. Also we do same, where both the DOLS and Johansen jointly find evidence of cointegration. This includes LM2, LY, LLE, LM2, LY LSEC, LDC, LSEC, LY, and finally LM3 LLE, and LY.

Thus, in summary, the most relevant variables to suggest a stable relationship between human capital and financial development are both the secondary school enrolment and the life expectancy, while the relevant financial development indicators are the domestic credit to the economy, broad money and liquid liabilities. The least important variable for long run stability is the primary school enrolment.

The tertiary enrolment has been negligible at an average of $6 \%$, thus its contribution has been small, also substantial part of the credit in the economy has often been channelled to the public sector, depriving the private sectors the much needed finance for the growth.

Financial development is proxy by the domestic credit to the economy, broad money and liquid liabilities. We conduct the causality tests using the first differenced VARs for pairs of variables for which the three techniques show evidence of cointegration. The results of the causality tests are reported in table 7. Two F-Tests and one t-test relating to the exclusion of relevant variables from the ECM are used. The null hypothesis is non-causation. There are two possible causations in the ECM-based test; these are the error correction term and the lagged dynamic terms. We also test for the joint significance of both the dynamic terms and the error correction term, which is also a test for strong exogeneity (See Charemza and Deadman 1992, Demetraides and Hussein 1996).

The results suggest that we reject the null hypothesis of no Granger causality from real GDP to financial sector, where credit to the private sector., while we cannot reject the nonGranger causality from real GDP to the financial sector where financial sector is measured by the broad Money or Liquid liability. However, there is no strong evidence to suggest that financial development Granger causes the real GDP, for all the measures used. This may be due to the underdevelopment of the financial sector in the period under review, and may equally give empirical credence to Joan Robinson hypothesis that "where enterprise leads finance follows". This is also in consonance with the findings of Demetriades and Hussein (1996) where they reject the hypothesis of non-causality from real output to financial development at $10 \%$ significance level in the case of South Africa (Pg 403) where they simply concluded that there is reverse causation in South Africa, Sri Lanka and Venezuela. It also suggest that the finance-growth link is not as firm as portrayed in the literature, hence 
consistent with Rousseau and Wachtel's (2009) recent empirical analysis, which also casts doubts on the strength of this link.

\section{Summary and Conclusion}

The study investigates the causal link between human capital and financial development in South Africa, the study finds a weak relationship between financial development and all the proxies of human capital used except life expectancy at birth and secondary school enrolment. The result is similar when applied to the proxy for growth and suggests that these two variables are the relevant indicators for human capital development in South Africa. These we attribute to the prevalence of HIV/AIDS in the country which determines their responsiveness to financial development or economic growth. Secondly, the importance of secondary school enrolment depicts the level of education of the workforce which currently stands at $90 \%$ of the entire workforce.

The indicators of financial development used suggest that domestic credit to the economy, broad money and liquid liabilities are good in explaining the relationship while credit to the private sector is found to be weak in this regard. This indicates that a substantial amount of credit is not channelled to the private sector, thus depriving the sector of the much needed finance. This observation could possibly explain the supply -leading causal relationship between finance and growth observed. Where the bulk of credit is channelled to the public sector, there is every tendency that the financial sector will be under-developed hence incapable to Granger cause growth.

The above observation suggests that the government should promote the educational level of their workforce beyond secondary level and reduce the prevalence of death threatening illnesses. They should also redirect credit from the public sector to the private sector which has been proven to be capable of ensuring better growth within the economy.

Table A1: Definition and Sources of Data

\begin{tabular}{|c|c|c|}
\hline Variable & Definition & Source \\
\hline $\begin{array}{l}\text { M3-Y (1965-2005) } \\
\text { Liquid Liabilities/GDP } \\
\text { (\%) }\end{array}$ & $\begin{array}{l}\text { Liquid liability is the sum of currency and deposits } \\
\text { in the central bank, plus transferable deposits } \\
\text { and M1, plus time and savings deposits, foreign } \\
\text { currency transferable deposits, certificates of } \\
\text { deposits, plus travellers' cheque, foreign } \\
\text { currency and time deposits, commercial paper } \\
\text { and shares of mutual funds or market funds held } \\
\text { by residents }\end{array}$ & $\begin{array}{l}\text { World Development } \\
\text { Indicators (2006) }\end{array}$ \\
\hline $\begin{array}{l}\text { Private Sector } \\
\text { Credit/GDP } \\
(\%)(1965-2005)\end{array}$ & $\begin{array}{l}\text { Financial resources provided to the private sector } \\
\text { such as through loans, purchase of non-equity } \\
\text { securities, and trade credits and other account } \\
\text { receivables that establish a claim for repayment }\end{array}$ & $\begin{array}{l}\text { World Development } \\
\text { Indicators (2006) }\end{array}$ \\
\hline $\begin{array}{l}\text { Domestic Credit } \\
\text { provided by the }\end{array}$ & $\begin{array}{l}\text { This includes all credit to various sectors on a } \\
\text { gross basis. The banking sector includes }\end{array}$ & $\begin{array}{l}\text { World Development } \\
\text { Indicators (2006) }\end{array}$ \\
\hline
\end{tabular}




\section{Macrothink}

Research in Applied Economics

ISSN 1948-5433

2012, Vol. 4, No. 3

\begin{tabular}{|c|c|c|}
\hline $\begin{array}{l}\text { Banking Sector/GDP } \\
(\%)(1965-2005)\end{array}$ & monetary authorities and deposit money banks & \\
\hline $\begin{array}{l}\text { M2-Y Broad } \\
\text { Money/GDP (\%) } \\
(1966-2005)\end{array}$ & $\begin{array}{l}\text { Sum of Currency and deposits in the Central } \\
\text { bank, plus time and savings deposits in banks }\end{array}$ & $\begin{array}{l}\text { World Development } \\
\text { Indicators (2006) }\end{array}$ \\
\hline LE & Life Expectancy at birth & $\begin{array}{l}\text { World Development } \\
\text { Indicators (2006) }\end{array}$ \\
\hline TER ENR & Tertiary school enrolment & $\begin{array}{l}\text { Centre for South Africa } \\
\text { studies and World } \\
\text { Development Indicators } \\
\text { (2006) }\end{array}$ \\
\hline SEC ENR & $\begin{array}{l}\text { Secondary school enrolment as a ratio of pupils } \\
\text { of school age }\end{array}$ & $\begin{array}{l}\text { Centre for South Africa } \\
\text { studies and World } \\
\text { Development Indicators } \\
\text { (2006) }\end{array}$ \\
\hline PRY-ENR & $\begin{array}{l}\text { Primary school enrolment rate as a ratio of Pupils } \\
\text { of primary school age }\end{array}$ & $\begin{array}{l}\text { Centre for South Africa } \\
\text { studies and World } \\
\text { Development Indicators } \\
\text { (2006) }\end{array}$ \\
\hline RGDPGR & Real GDP per Capita growth rate & $\begin{array}{l}\text { World Development } \\
\text { Indicators (2006) }\end{array}$ \\
\hline
\end{tabular}

Table 1: Descriptive Statistics

\begin{tabular}{cccccccccccc}
\hline & DC_GD & DCP_ & & & M2_ & M3_- & PRY_ & & SEC_ & TER & \\
$\mathrm{N}=41$ & $\mathrm{P}$ & GDP & I_Y & LE & GDP & GDP & ENR & RGDPGR & ENR & ENR & N=41 \\
\hline Mean & 62.3 & 87.7 & 22.1 & 55 & 53.5 & 51 & 73.5 & 0.9 & 69.9 & 13.8 & Mean \\
Median & 59.3 & 72.7 & 20.8 & 55.5 & 53 & 50.6 & 72.4 & 1.05 & 72.4 & 13.6 & Median \\
Maximum & 86.1 & 146.8 & 33.4 & 62.9 & 66.3 & 62.3 & 100 & 6.3 & 94.3 & 15.9 & Maximum \\
Minimum & 51.5 & 55.6 & 14.3 & 44.6 & 45.2 & 38.4 & 43.4 & -4.3 & 43.4 & 12.1 & Minimum \\
Std Dev & 8.8 & 29.1 & 5.4 & 5.1 & 4.7 & 7.1 & 19.9 & 2.7 & 16.3 & 1.1 & Std Dev \\
Skewness & 1.4 & 0.7 & 0.2 & -0.4 & 0.4 & -0.1 & -0.07 & -0.1 & -0.2 & 0.3 & Skewness \\
Kurtosis & 4.3 & 1.9 & 1.7 & 2.2 & 2.8 & 1.6 & 1.5 & 2.5 & 1.7 & 1.9 & Kurtosis \\
Jarque-Bera & 17.9 & 5.7 & 3.2 & 2.1 & 0.9 & 3.1 & 3.7 & 0.5 & 3.1 & 2.7 & Jarque-Bera \\
Probability & 0.00012 & 0.05 & 0.2 & 0.3 & 0.6 & 0.2 & 0.2 & 0.8 & 0.2 & 0.3 & Probability \\
\hline
\end{tabular}




\section{MIMacrothink}

Table 2: Correlation Matrix

\begin{tabular}{|c|c|c|c|c|c|c|c|c|c|c|}
\hline $\mathrm{N}=41$ & DC_GDP & DCP_GDP & I_Y & LE & $\begin{array}{l}\mathrm{M}_{2} \\
\mathrm{GDP}\end{array}$ & M3_GDP & $\begin{array}{c}\text { PRY } \\
\text { ENR }\end{array}$ & RGDPGR & $\begin{array}{c}\text { SEC_ } \\
\text { ENR }\end{array}$ & $\begin{array}{l}\text { TER } \\
\text { ENR }\end{array}$ \\
\hline DC_GDP & 1 & & & & & & & & & \\
\hline DCP_GDP & 0.83 & 1 & & & & & & & & \\
\hline I_Y & -0.46 & -0.79 & 1 & & & & & & & \\
\hline LE1 & -0.82 & -0.49 & 0.05 & 1 & & & & & & \\
\hline M2_GDP & 0.24 & 0.1 & 0.01 & -0.24 & 1 & & & & & \\
\hline M3_GDP & 0.08 & -0.42 & 0.67 & -0.46 & 0.22 & 1 & & & & \\
\hline PRY_ENR & 0.55 & 0.86 & -0.84 & -0.09 & 0.05 & -0.73 & 1 & & & \\
\hline RGDPGR & 0.32 & 0.09 & 0.27 & -0.57 & -0.08 & 0.42 & -0.2 & 1 & & \\
\hline SEC_ENR & 0.44 & 0.75 & -0.81 & 0.06 & 0.05 & -0.72 & 0.94 & -0.24 & 1 & \\
\hline TER_ENR & 0.14 & -0.17 & 0.47 & -0.35 & 0.21 & 0.52 & -0.22 & 0.17 & -0.2 & 1 \\
\hline
\end{tabular}

Note: $\mathrm{DC}-\mathrm{GDP}=$ Domestic Credit to the economy/GDP, DCP-GDP= Domestic Credit to the private sector /GDP; I-Y= Gross Capital Formation/GDP; LE= Life Expectancy at Birth; M2-GDP= M2/GDP; M3-GDP=M3/GDP; PRY-ENR= Primary school Enrolment; RGDPGR= Real GDP growth rate; SEC-ENR= Secondary school Enrolment; TER-ENR= Tertiary School Enrolment.

\section{References}

Acemoglu, D., Johnson, S., \& Robinson, J. (2001). The Colonial Origins of Comparative Development: An Empirical Investigation. American Economic Review, 91, 1369-1401.

Aghion, P., \& Howitt, P. (1998). Endogenous Growth Theory. MIT Press, Cambridge, Mass.

Ainsworth, M., \& Over, M. (1994). Aids and African Development. World Bank Research Observer, The World Bank 9 (2) 203-240.

Arellano, M., \& Bond, S. (1991). Some tests of specification for Panel data: Monte-carlo evidence and an application to employment equations. Review of Economic Studies, 58, 277-297.

Arestis, P., \& Demetriades P. (1997) Financial Development and Economic Growth: Assessing the Evidence. Economic Journal, 107, 783-799.

Balassa, B. (1986). Policy Responses to Exogenous Shocks in Developing Countries. The American Economic Review, 76(2), 75-78.

Baltagi, B. (1995). Econometric Analysis of Panel Data. New York: John Wiley and Sons.

Barro, R. (1991). Economic Growth in a Cross-Section of Countries. Quarterly Journal of Economics, 106, 407-443. 


\section{Macrothink}

Barro, R. (1999). Human Capital and Growth in Cross-Country Regressions. Swedish Economic Policy Review, 6(2), 237-277.

Barro, R. (2001). Human Capital and growth. American Economic Review, May, 19(2), 12-17.

Barro, R., \& Lee, J (1994) Sources of Economic Growth Carnegie-Rochester Conference Series on Public Policy, 40, June.

Barro, R., \& Lee,J. (2001). International Data on Educational Attainment: Updates and Implications". Oxford Economic Papers, July 53(3), 541-63.

Barro, R., \& Sala-i-martin, X. (1999). Economic Growth. Cambridge: The MIT Press.

Baumol, W. (1986). Productivity Growth, Convergence and Welfare: What the long-run Data show? American Economic Review, 76, 1072-1085.

Beck, T. (2003) Financial Development and International Trade. Is there a Link?” The World Bank Group Working Paper, No. 2608.

Benhabib, J., \& Spiegel, M, (1994). The role of Human Capital in Economic Development: Evidence from Aggregate Cross-Country Data. Journal of Monetary Economics, 34, 143-173.

Bloom D., Canning, D., \& Sevilla J. (2004). The Effect of Health on Growth: A Production Function Approach. World Development, 32(1), January 2004, pp. 1-13.

Bloom, D., \& Sachs, J. (1998). Geography, Demography and Economic Growth in Africa. Brookings Papers on Economic Activity, 207-73.

Collier, P., \& Gunning, J. (1999). Explaining African Economic Performance". Journal of Economic Literature, March, 37(1), 64-111.

Collier, P., \& Gunning, J. (1999). Why has Africa Grown Slowly?. Journal of Economic Perspectives, Summer, 13(3), 3-22.

David, P. (2001). Knowledge, Capabilities and Human Capital Formation in Economic Growth. New Zealand Treasury Working Paper, 01/13 June, 1-147.

De Gregorio, J. (1996). Borrowing Constraints, Human Capital Accumulation and Growth. Journal of Monetary Economics, 37, 49-71.

De Gregorio, J., \& Guidotti, P. (1995). Financial Development and Economic Growth. World Development, 23, 433-448.

De la Fuente, A., \& Domeneh, R. (2000). Human Capital in Growth Regressions: How Much Difference Does Data Quality Make?. CEPR Discussion Paper No 2466, May.

Demetriades, P., \& Andrianova, S. (2004). Finance and Growth: What We Know and We Need to Know' in Goodhart, C. (ed.), Financial Development and Economic Growth: Explaining the Links, 38-65. Palgrave Macmillan, Basingstoke. 


\section{Macrothink}

Demetriades, P., \& Hussein, K. (1996). Does Financial Development Cause Economic Growth? Time Series Evidence from 16 Countries. Journal of Development Economics, $51,387-411$.

Easterly, W., \& Levine, R (1997). Africa's Growth Tragedy: Policies and Ethnic Divisions. Quarterly Journal of Economics, 112, 1203-1250.

Estrada, G., Park, D., \& Ramayandi, A. (2010) Financial Development and Economic Growth in Developing Asia. ADB Working Paper Series No. 233, November.

Evans, D., Green, C., \& Murinde, V. (2002). Human Capital and Financial Development in Economic Growth: New Evidence Using the Translog Production Function. International Journal of Finance and Economics, 7, 123-140.

Feldman, D., \& Gang, I. (1990). Financial Development and the Price of Services. Economic Development and Cultural Change 38(2), Jan.

Hojo, M. (2003). An Indirect Effect of Education on Growth. Economics Letters, 80, 31-34.

Honohan, P. (2004). Financial Development, Growth and Poverty: How Close are the Links? In Goodhart, C. (ed.), Financial Development and Economic Growth: Explaining the Links, 38-65. Palgrave Macmillan, Basingstoke.

IMF (2005), Regional Economic Outlook Sub-Saharan Africa. World Economic and Financial Surveys.

Islam, N. (1995). Growth Empirics: A Panel Data Approach. The Quarterly Journal of Economics, 110(4), 1127-1170.

Islam, N. (1998). Growth Empirics: A Panel Data Approach...A Reply. The Quarterly Journal of Economics, 113 (1), 325-329.

Kevin, L, Pesaran, M., \& Smith, R. (1998). Growth Empirics: A Panel Data Approach.. A Comment. The Quarterly Journal of Economics, 113(1), 319-323.

King, R., \& Levine, R. (1993). Finance and Growth: Schumpeter Might be Right. Quarterly Journal of Economics, 108, 717-737.

Knack, S., \& Keefer, P. (1995). Institutions and Economic Performance: Cross Country tests Using Alternative Institutional Measures. Journal of Economics and Politics, 207 227.

La Porta, R., Lopez-de-Silanes, F., Shleifer, A., \& Vishny, R. (1997). Legal Determinants of External Finance. Journal of Finance, 52, 1131 - 1150.

Landau, D. (1986). Government and Economic Growth in Less Developed Countries: An Empirical Study for 1960-1980. Economic Development and Cultural Change, 35(1) Oct. pp 35-75.

Levine, R (1997). Financial Development and Economic Growth: Views and Agenda. Journal of Economic Literature, 35, June 688-726. 


\section{Macrothink}

Research in Applied Economics

ISSN 1948-5433

2012, Vol. 4, No. 3

Levine, R. (2003). More on Finance and Growth: More Finance, More Growth? Federal Reserve Bank of St. Louis Review, 85(4), 31-46.

Mankiw, N., Romer,D., \& Weil, D. (1992). A Contribution to the Empirics of Economic Growth. Quarterly Journal of Economics, 407-437.

McDonald, S., \& Roberts, J. (2002). Growth and Multiple Forms of Human Capital in an Augmented Solow Model: A Panel Data Investigation. Economics Letters, 74(2), 271-276.

McKinnon, R. (1973). Money and Capital in Economic Development. Brookings Institution, Washington, DC.

Outreville, J. (1999). Financial Development, Human Capital and Political Stability. UNCTAD Discussion Paper No 142.

Pagano, M. (1993). Financial Markets and Growth; An Overview. European Economic Review, 37 April pp 613-622.

Papagni, E. (2006). Household Borrowing Constraints, Fertility Dynamics and Economic Growth. Journal of Economic Dynamics and Control. Jan 27-54.

Pesaran, M., Shin, Y., \& Smith, R. (1999). Pooled Mean Group Estimation of Dynamic Heterogeneous Panels. Journal of American Statistical Association, 94, 621-634.

Rajan, R., \& Zingales, L. (2003). The Great Reversals: The Politics of Financial Development in the Twentieth Century. Journal of Financial Economics, 69, 5 - 50.

Romer, P. (1986). Increasing Returns and Long-Run Growth. Journal of Political Economy, 94, 1002-1038.

Romer, P. (1989). Human Capital and Growth: Theory and Evidence," NBER, Working Paper. No 3173, Nov.

Romer, P. (1990). Human Capital and Growth: Theory and Evidence". Carnegie-Rochester Conference Series on Public Policy, 32, 251-86.

Rousseau, P., \& Wachtel, P. (2009). What is Happening to the Impact of Financial Deepening on Economic Growth?. Department of Economics, Vanderbilt University, Working Paper No. 09-W15.

Sachs, J., \& Warner, A. (1997). Sources of Slow Growth in African Economies. Journal of African Economies, Oct, 6(3), 335-76.

Schultz, T. (1961). Investment in Human Capital. American Economic Review, 1-17.

Schultz, T. (1999). Health and Schooling Investment in Africa. Journal of Economic Perspectives 13(3), Summer 67-88.

Shaw, E. (1973). Financial Deepening in Economics Development. Oxford University Press, New York. 
Temple, J. (1999). A Positive Effect of Human Capital on Growth. Economics Letters, Oct 65(1), 131-134.

Temple, J. (1999). The New Growth Evidence, Journal of Economic Literature, March.

Ukenna, S., Ijeoma, N., Anionwu, C., \& Olise, M. (2010). Effect of Investment in Human Capital Development on Organisational Performance: Empirical Examination of the Perception of Small Business Owners in Nigeria. European Journal of Economics, Finance and Administrative Sciences, Issue 26.

World Bank (2005). World Development Indicators. Washington D.C.: World Bank.

\section{Copyright Disclaimer}

Copyright reserved by the author(s).

This article is an open-access article distributed under the terms and conditions of the Creative Commons Attribution license (http://creativecommons.org/licenses/by/3.0/). 